\title{
Analisis Pengaruh Aspek Budaya dalam Penerjemahan Ujaran pada Novel Eclipse
}

\section{Karya Stephenie Meyer}

\author{
Tri Pujiati \\ Universitas Pamulang \\ tpujiati.unpam@gmail.com
}

\begin{abstract}
Abstrak
Penelitian ini bertujuan untuk melihat pengaruh budaya terhadap penerjemahan ujaran dalam novel Eclipse karya Stephenie Meyer dari bahasa Inggris ke dalam bahasa Indonesia. Tujuan khusus yang ingin dicapai dari penelitian ini adalah untuk mengetahui (1) strategi penerjemah dalam mengalihkan pesan dari TSu ke TSa; (2) ideologi penerjemahan dilihat dari perspektif semiotik; (3) tanggapan pembaca terkait kesepadanan, keberterimaan, dan keterbacaan penerjemahan. Penelitian ini menggunakan pendekatan kualitatif dengan metode analisis isi. Data yang digunakan sebanyak 30 ujaran. Berdasarkan hasil penelitian, dapat disimpulkan bahwa (1) strategi yang digunakan oleh penerjemah adalah reduksi $34 \%$, parafrasa $23 \%$, kuplet $23 \%$, perluasan 10\%, shift 7\%, transposisi 3\%; (2) ideologi yang lebih dominan digunakan adalah ideologi domestikasi yang berorientasi pada bahasa sasaran sebanyak $87 \%$ dan 13\% menggunakan ideologi foreignisasi, hal ini membuktikan bahwa budaya sangat berpengaruh terhadap penerjemahan ujaran; (3) berdasarkan resepsi dari pembaca terkait dengan kesepadanan, keberterimaan, dan keterbacaan, dapat dilihat bahwa kualitas terjemahan ini sangat akurat dan pembaca dapat memahami makna yang disampaikan dalam teks sasaran. Rekomendasi dari penelitian ini bahwa dalam menerjemahkan sebuah teks dari Bsu dan BSa yang memiliki latar belakang budaya yang berbeda, seorang penerjemah bisa melihat dengan perspektif semiotik untuk mengetahui hubungan antara budaya sehingga pesan yang disampaikan dapat berterima oleh pembaca sasaran.
\end{abstract}

Kata Kunci : budaya, penerjemahan, ujaran, novel

\section{A. Latar Belakang}

Menerjemahkan karya sastra bukan hanya mengalihkan pesan atau mencari padanan dari bahasa sumber ke dalam bahasa sasaran, tetapi menerjemahkan ide dan tujuan pengarang sehingga pesan asli dan tujuan penulisan pesan itu sendiri sampai kepada pembaca, (Nord, 1997: 80-84). Newmark (1988: 170) mengatakan bahwa ungkapan-ungkapan yang ada pada dialog novel seringkali berupa implikatur-implikatur yang sarat makna berdasarkan konteks sosiokultural pengguna bahasa sumber sehingga 
penerjemah harus mampu mencari padanannya sesuai dengan konteks sosiobudaya pengguna bahasa sasaran.

Penerjemahan adalah upaya untuk mengungkapkan kembali pesan yang terdapat dalam teks suatu bahasa atau teks sumber ke dalam bentuk teks dalam bahasa lain atau teks sasaran, sehingga bisa dikatakan bahwa teks adalah bahasa. Bahasa merupakan sistem tanda-tanda yang masing-masing terdiri atas aspek bentuk (signifiant) dan aspek makna (signifie). Tidak hanya itu, Hoed (2006: 28) mengatakan bahwa dalam bahasa berupa tulisan (teks), aspek bentuk adalah apa yang terbaca dan diserap oleh pikiran dan aspek makna berada di balik yang terbaca dan ditafsirkan oleh pembaca.

Pada penerjemahan, tentu ada pesan yang ingin disampaikan dalam bentuk teks yang tidak bisa terlepas dari konteks dan situasi tempat teks tersebut diproduksi dan ditafsirkan oleh pembaca sehingga kita harus melihat teks sebagai sebuah tanda bahasa, Hoed (2006: 28). Tidak hanya itu, satu hal yang sangat menarik dalam penerjemahan adalah perbedaan budaya yang ada pada teks sumber dan teks sasaran. Penerjemah dihadapkan pada kendala budaya yang berbeda sehingga menyulitkan dalam mengalihkan pesan dari teks sumber ke dalam teks sasaran. Terkait dengan penerjemahan, Hoed (2006: 97-98) mengatakan bahwa kebudayaan adalah cara hidup yang perwujudannya terlihat dalam bentuk perilaku serta hasilnya terlihat secara material yang diperoleh melalui pembiasaan dari satu generasi ke generasi yang lain sehingga tidak ada kebudayaan yang sama. Dengan demikian, bisa dikatakan bahwa pada saat mengalihkan pesan dari teks sumber ke dalam teks sasaran pasti akan mengalami perbedaan dalam konstruksinya.

\section{B. Kajian Pustaka}

Newmark (1988:5) mendefinisikan penerjemahan sebagai "rendering the meaning of a text into another language in the way that the author intended the text" (menerjemahkan makna suatu teks ke dalam bahasa lain sesuai dengan yang dimaksudkan pengarang). Konsep penerjemahan yang diungkapkan oleh Newmark lebih menekankan bahwa penerjemahan bukan hanya mengalihkan pesan dari bahasa sumber ke dalam bahasa sasaran tetapi harus memahami bahasa sasaran dan maksud yang ingin disampaikan oleh pengarang agar tidak terjadi kesalahan.

Bell (1991: 5) mendefinisikan penerjemahan sebagai "Translation is the expression in another language (or target language) of what has been expressed in 
another, source language, preserving semantic, and stylistic equivalences." Penerjemahan sebagai suatu bentuk pengungkapan suatu bahasa dalam bahasa lainnya sebagai bahasa sasaran, dengan memperhatikan semantik dan ekuivalensi.

Penerjemahan merupakan pengalihan pesan dari teks sumber ke dalam teks sasaran dari kedua bahasa yang berbeda. Perbedaan bahasa seringkali menimbulkan kesulitan dalam penerjemahan sehingga membutuhkan sebuah cara yang disebut dengan strategi penerjemahan. Newmark kurang lebih memberikan 17 alternatif strategi penerjemahan. Strategi penerjemahan yang diungkapkan oleh Newmark adalah penerjemahan harfiah, transferensi, naturalisasi, kesepadanan budaya, kesepadanan fungsional, kesepadanan deskriptif, sinonim, calque, modulasi, penerjemahan resmi, penerjemahan label, kompensasi, analisis komponen, pengurangan dan perluasan, parafrasa, dan kuplet. Berikut ini penjelasan tentang strategi penerjemahan Newmark :

1. Penerjemahan Harfiah. Prosedur ini meminjam ekspresi BSu dengan struktur BSa frasa ini diterjemahkan secara harfiah dari bahasa Inggris yang kemudian disesuaikan dengan struktur kaidah bahasa Indonesia.

2. Transferensi merupakan sebuah istilah yang digunakan oleh Newmark untuk menjelaskan prosedur penerjemahan dengan mentransfer sebuah kata dalam BSu ke dalam BSa. Vinay dan Darbelnet dan Bell menyebut istilah tersebut dengan borrowing (peminjaman), Mona baker menyebutnya dengan penerjemahan dengan kata pinjaman, sedangkan Hoed menyebutnya 'tidak diberikan padanan'. Prosedur ini digunakan oleh penerjemah jika terdapat teks yang tidak dikenal dalam budaya BSa dan mengacu pada tempat atau situasi tertentu yang khas dalam budaya BSu.

3. Naturalisasi. Prosedur ini merupakan bentuk transferensi. Namun jika dalam transferensi kata dalam TSu dipinjam begitu saja, dalam naturalisasi terdapat penyesuaian lafal atau ejaan kata asing. Prosedur ini menyesuaikan bunyi sehingga disebut juga penerjemahan fonologis oleh Hoed. Prosedur penerjemahan ini dilakukan jika penerjemah tidak dapat menemukan padanan yang sesuai dalam BSa sehingga memutuskan untuk membuat kata baru yang diambil dari bunyi kata itu dalam BSu untuk disesuaikan dengan sistem bunyi dan ejaan. Misalnya 'cryptographic software' menjadi 'perangkat lunak kriptografis'. Pada contoh tersebut, dapat dilihat bahwa 
cryptographic dalam TSu disesuaikan lafalnya pada bahasa sasaran menjadi kriptografis.

4. Kesepadanan Budaya. Kesepadanan budaya yang diungkapkan oleh Newmark dengan tujuan agar terjemahan dapat mudah diterima oleh pembaca karena kata budaya tersebut tidak terdapat pada bahasa sasaran.

5. Padanan Fungsional. Pengalihan kata BSu terutama kata budaya menjadi kata budaya yang bersifat bebas atau bahkan membentuk istilah khusus baru yang pada dasarnya menetralisir kata budaya tersebut.

6. Kesepadanan deskriptif yaitu untuk menjelaskan makna atau istilah atau idiom yang tidak ada padanannya dalam BSa. Prosedur ini hanya mengalihkan makna dalam BSu tetapi tidak mempertahankan bentuk.

7. Sinonim. Menurut Newmark, prosedur penerjemahan sinonim merupakan pemilihan kata dalam BSa yang yang mendekati arti dalam Bsu karena dalam BSu tidak terdapat kata yang memiliki arti yang sepadan dalam BSu.

8. Through Translation. Newmark menggunakan istilah through translation untuk strategi penerjemahan dalam menerjemahkan ungkapan idiomatis dari TSu ke dalam TSa meskipun hasilnya terasa sebagai sesuatu yang asing. Bell dan Baker menyebutnya dengan istilah loan translation/ calque.

9. Shifts atau Transposisi adalah prosedur penerjemahan yang melibatkan perubahan gramatikal dari teks sumber ke dalam teks sasaran, seperti perubahan dari singular ke plural. Kedua, pergeseran terjadi ketika struktur gramatikal tidak terdapat dalam teks sasaran. Machali dan Hoed menyebut prosedur ini sebagai transposisi. Misalnya pada penerjemahan 'a pair of trousers' menjadi 'sebuah celana'. ]

10. Modulasi. Prosedur penerjemahan yang dilakukan dengan mengubah perspektif, sudut pandang atau segi maknawi yang lain. Modulasi wajib juga terjadi pada penerjemahan kata yang hanya sebagian aspek maknanya dalam BSu dapat diungkapkan dalam BSa, yaitu dari makna yang bernuansa khusus ke umum.

11. Penerjemahan Resmi atau Baku. Newmark mendefinisikan penerjemahan resmi sebagai sebuah penerjemahan istilah nama dan ungkapan yang sudah resmi dalam BSa sebagai padanan. Hoed menggunakan penerjemahan resmi 
atau baku untuk sejumlah istilah, nama, dan ungkapan yang sudah baku atau resmi dalam BSa sehingga penerjemah langsung menggunakannya sebagai padanan. Biasanya istilah sudah ada dalam undang-undang glosari di bidang tertentu, atau berupa nama orang, kota, atau wilayah.

12. Analisis Komponen. Analisis komponen makna digunakan untuk membandingkan kata dalam TSu dan TSa yang mempunyai makna serupa. Biasanya kata dalam BSu memiliki makna yang lebih spesifik daripada kata BSa. Dengan demikian penerjemah harus menambah komponen makna dalam TSa untuk menghasilkan makna yang paling dekat.

13. Reduksi dan Perluasan. Newmark memberikan definisi mengenai reduksi sebagai sebuah prosedur untuk mengurangi kata yang terdapat dalam TSu, karena makna dalam teks sumber sudah dapat dipahami, meskipun tanpa kata tersebut. Sementara perluasan adalah menambahkan kata tertentu tanpa menambahkan makna dalam TSa.

14. Kompensasi. Newmark mendefinisikan prosedur kompensasi dalam penerjemahan bisa digunakan jika terdapat bagian dalam sebuah kalimat yang tidak dapat diterjemahkan. Bagian teks tersebut dikompensasi pada bagian lain dalam teks sasaran.

15. Kuplet. Prosedur yang terjadi apabila penerjemah menggabungkan dua prosedur yang berbeda.

16. Parafrasa. Parafrasa digunakan jika dalam BSa tidak ditemukan padanan istilah atau idiom yang tepat. Dengan parafrasa, biasanya terjemahan lebih panjang atau lebih pendek.

17. Catatan Kaki. Newmark memberikan definisi mengenai penerjemahan dengan catatan kaki untuk memperjelas makna kata terjemahan yang dimaksud, karena tanpa penjelasan tambahan itu kata terjemahan diperkirakan tidak dipahami secara baik oleh pembaca. Hoed menambahkan bahwa catatan kaki digunakan jika diperkirakan kata terjemahan tidak dapat dipahami secara baik oleh pembaca. Hal ini dilakukan apabila catatan itu panjang sehingga kalau ditempatkan dalam teks akan mengganggu pembaca.

Menurut Hoed (2006: 83), ideologi dalam penerjemahan adalah prinsip atau keyakinan tentang benar atau salah dalam penerjemahan. Hoed mengutip pernyataan 
Basnett dan Lafevere mengatakan bhawa ideologi adalah prinsip yang dipercayai kebenarannya oleh sebuah komunitas dalam suatu masyarakat. Ideologi yang digunakan penerjemah dalam mengalihkan pesan yang sering digunakan adalah ideologi domestikasi dan foreignisasi. Venuti dalam Hoed (2006: 14) mengatakan bahwa ideologi domestikasi mengacu pada bahasa sasaran, yaitu bahwa terjemahan yang betul, berterima, dan baik adalah yang sesuai dengan cita rasa masyarakat bahasa sasaran. Sedangkan kebalikannya adalah ideologi foreignisasi yaitu ideologi yang berorientasi pada bahasa sumber, yakni bahwa yang betul, berterima, dan baik adalah yang sesuai dengan selera dan harapan pembaca, serta penerbit yang menginginkan kehadiran kebudayaan bahasa sumber atau yang menganggap kehadiran kebudayaan asing bermanfaat bagi masyrakat.

\section{Metode Penelitian}

Penelitian ini menggunakan pendekatan kualitatif dengan metode analisis isi dan pendekatan fungsional dalam bidang penerjemahan dengan perspektif semiotik. Pendekatan fungsional dalam bidang penerjemahan digunakan sebagai dasar memahami penerjemahan sedangkan pendekatan semiotik digunakan untuk melihat hubungan antara tanda, penanda, dan petanda dalam Tsu dan Tsa untuk melihat ideologi penerjemahan. Analisis data dalam penelitian ini dilakukan dengan menggunakan ancangan penelitian kualitatif. Data pada penelitian ini adalah ujaran yang terdapat pada dialog novel. Adapun sember data pada penelitian ini yaitu Eclipse karya Stephenie Meyer yang diterbitkan Little Brown Company, New York dengan 27 bab dan tebal 629 pada tahun 2007. Novel ini diterjemahkan oleh Monica Dwi Chresnayani ke dalam bahasa Indonesia dengan 27 bab dan tebal 684 oleh PT Gramedia Pustaka Utama, Jakarta pada tahun 2008 .

Teknik pengumpulan data dilakukan melalui dua tahap, yaitu tahap pertama dengan membaca TSu dan Tsa dengan seksama, dan tahap kedua dilakukan dengan cara mengidentifikasi semua ujaran yang terdapat dalam TSu dan Tsa. Untuk melihat tanggapan pembaca terkait dengan kualitas terjemahan, saya akan menggunakan skala penilaian yang telah dimodifikasi oleh Nababan (2004) sebagaimana telah digunakan Rudi Hartono dengan disertasinya yang berjudul "Penerjemahan Idiom dan Gaya Baasa (Metafora, Kiasan, Personifikasi, dan Aliterasi) dalam Novel To Kill A Mockingbird dari Bahasa Inggris ke Bahasa Indonesia (Pendekatan Kritik Holistik)”. Berikut ini 
skala penilaian yang akan digunakan untuk melihat respon pembaca terkait dengan penerjemahan novel ini.

Pada tingkat kesepadanan, hasil terjemahan dinilai dengan skala berurutan, skala 3 (akurat), skala 2 (kurang akurat), skala 1 (tidak akurat).

\begin{tabular}{|c|l|l|}
\hline Skala & \multicolumn{1}{|c|}{ Indikator } & \multicolumn{1}{|c|}{ Simpulan } \\
\hline 3 & $\begin{array}{l}\text { Makna kata, frasa, klausa dan kalimat bahasa sumber } \\
\text { dialihkan secara akurat ke dalam bahasa sasaran; } \\
\text { sama sekali tidak ada distorsi. }\end{array}$ & Akurat \\
\hline 2 & $\begin{array}{l}\text { Sebagian besar makna kata, frasa, klausa dan kalimat } \\
\text { bahasa sumber dialihkan secara akurat ke dalam } \\
\text { bahasa sasaran. Namun, masih terdapat distorsi } \\
\text { makna yang mengganggu keutuhan pesan. }\end{array}$ & \\
\hline 1 & $\begin{array}{l}\text { Makna kata, frasa, klausa dan kalimat bahasa sumber } \\
\text { dialihkan secara tidak akurat ke dalam bahasa } \\
\text { sasaran. }\end{array}$ & Tidak Akurat \\
\hline
\end{tabular}

Pada tingkat keberterimaan, hasil terjemahan dinilai dengan skala berurutan, skala 3 (berterima), skala 2 (kurang berterima), skala 1 (tidak berterima).

\begin{tabular}{|c|l|l|}
\hline Skala & \multicolumn{1}{|c|}{ Indikator } & \multicolumn{1}{|c|}{ Simpulan } \\
\hline 3 & $\begin{array}{l}\text { Terjemahan terasa alamiah, istilah yang digunakan } \\
\text { lazim dan akrab bagi pembaca, kata, frasa, klausa dan } \\
\text { kalimat yang digunakan sudah sesuai dengan kaidah- } \\
\text { kaidah bahasa Indonesia. }\end{array}$ & Berterima \\
\hline 2 & $\begin{array}{l}\text { Pada umumnya terjemahan sudah terasa alamiah, } \\
\text { namun ada sedikit masalah pada penggunaan istilah, } \\
\text { terjadi sedikit kesalahan gramatikal. }\end{array}$ & Kurang Berterima \\
\hline 1 & $\begin{array}{l}\text { Terjemahan tidak alamiah atau terasa janggal dan } \\
\text { istilah yang digunakan tidak lazim, kata, frasa, klausa, } \\
\text { dan kalimat yang digunakan tidak sesuai dengan } \\
\text { kaidah-kaidah bahasa Indonesia. }\end{array}$ & \\
\hline
\end{tabular}


Pada tingkat keterbacaan, hasil terjemahan dinilai dengan skala berurutan, skala 3 (tingkat keterbacaan tinggi), skala 2 (tingkat keterbacaan sedang), skala 1 (tingkat keterbacaan rendah).

\begin{tabular}{|c|l|l|}
\hline Skala & \multicolumn{1}{|c|}{ Indikator } & \multicolumn{1}{|c|}{ Simpulan } \\
\hline 3 & $\begin{array}{l}\text { Kata, frasa, klausa dan kalimat terjemahan dapat } \\
\text { dipahami dengan mudah oleh pembaca. }\end{array}$ & $\begin{array}{l}\text { Tingkat keterbacaan } \\
\text { tinggi }\end{array}$ \\
\hline 2 & $\begin{array}{l}\text { Pada umumnya terjemahan dapat dipahami oleh } \\
\text { pembaca, namun ada bagian tertentu yang harus } \\
\text { dibaca lebih dari satu kali untuk memahami } \\
\text { terjemahannya. }\end{array}$ & $\begin{array}{l}\text { Tingkat keterbacaan } \\
\text { sedang }\end{array}$ \\
\hline 1 & $\begin{array}{l}\text { Terjemahan sulit dipahami oleh pembaca. } \\
\text { Tingkat keterbacaan } \\
\text { rendah }\end{array}$ \\
\hline
\end{tabular}

Tahapan analisis data pada penelitian ini dilakukan melalui prosedur berikut ini:

1) Membandingkan TSu dan Tsa untuk melihat ujaran serta masalah yang dihadapi oleh penerjemah dalam mengalihkan karena adanya perbedaan budaya dan struktur sintaksis Bsu dan BSa.

2) Menganalisis data untuk menemukan strategi yang digunakan oleh penerjemah dalam menerjemahkan ujaran.

3) Menganalisis data untuk melihat hubungan antara tanda, penanda, dan petanda dari kaca mata semiotik untuk melihat ideologi penerjemahan yang digunakan oleh penerjemah dalam mengalihkan pesan dari TSu ke Tsa.

4) Menganalisis data berdasarkan penilaian pembaca terkait kesepadanan, keberterimaan, dan keterbacaan terjemahan.

\section{Pembahasan}

\section{Strategi Penerjemahan Ujaran Novel Eclipse Karya Stephenie Meyer dari}

\section{Bahasa Inggris ke dalam Bahasa Indonesia}

Berdasarkan analisis terhadap 30 data yang dijadikan sampel penelitian, dapat dilihat strategi yang digunakan oleh penerjemah dalam mengalihkan pesan dari TSu ke Tsa seperti pada tabel berikut:

\begin{tabular}{|l|l|c|}
\hline \multicolumn{1}{|c|}{ Strategi Penerjemahan } & \multicolumn{1}{|c|}{ No Urut Data } & Jumlah \\
\hline Shift & 001,004 & 2 \\
\hline
\end{tabular}




\begin{tabular}{|l|l|c|}
\hline Transposisi & 002 & 1 \\
\hline Perluasan & $012,016,022$ & 3 \\
\hline Reduksi & $005,006,007,008,009,010,011,013,014,018$ & 10 \\
\hline Parafrasa & $003,015,023,024,026,027,028$ & 7 \\
\hline Kuplet & $017,019,021,021,025,029,030$ & 7 \\
\hline
\end{tabular}

Adapun grafikberikut menunjukkan sajian data terkait strategi penerjemahan ujaran yang digunakan oleh penerjemah.

\section{Strategi Penerjemahan Ujaran}

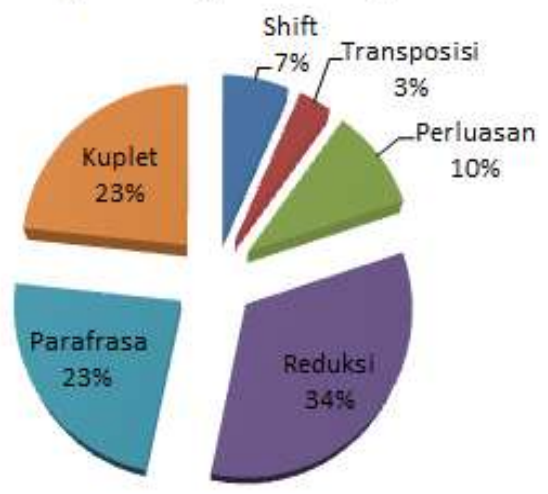

\section{Grafik Sebaran Strategi Penerjemahan Ujaran Novel Eclipse}

Analisis data terkait dengan strategi penerjemahan ujaran dapat dilihat pada tabel berikut ini:

\begin{tabular}{|c|c|c|}
\hline $\begin{array}{l}\text { No } \\
\text { Data }\end{array}$ & Tsu & Tsa \\
\hline 019 & $\begin{array}{l}\text { The jar of spagethi sauce } \\
\text { Charlie'd stuck in the } \\
\text { microwave was only on its first } \\
\text { revolution when I yanked the } \\
\text { door open and pulled it out. } \\
\text { What did I do wrong?" } \\
\text { Charlie demanded. } \\
\text { "You are supposed to take the } \\
\text { lidd off first, Dad. Metal's bad } \\
\text { for microwaves." } \\
\text { (Eclipse:5) }\end{array}$ & $\begin{array}{l}\text { Stoples berisi saus spageti yang } \\
\text { dimasukkan Charlie ke microwave baru } \\
\text { berputar sekali waktu aku menyentakkan } \\
\text { pintunya hingga terbuka dan } \\
\text { mengeluarkan stoples itu. } \\
\text { "Lho, apa salahku?” } \\
\text { tuntut Charlie. } \\
\text { "Buka dulu tutupnya, Dad. Logam tidak } \\
\text { bisa dimasukkan ke microwave." }\end{array}$ \\
\hline
\end{tabular}


Pada teks novel terjemahan di atas, dapat dilihat bahwa pada ujaran yang diturkan oleh Charlie dengan menggunakan kalimat tanya "What did I do wrong?" yang diterjemahkan menjadi “Lho, apa salahku”. Kalimat tanya tersebut diujarkan oleh Charlie untuk menanyakan bahwa dia tidak salah dalam memasak. Charlie menggunakan ujaran dalam bentuk kalimat tanya WH question. Pada terjemahan ujaran, penerjemah menggunakan kata budaya yaitu tho meskipun dalam teks bahasa Inggris tidak terdapat kata yang menunjukkan terjemahan tersebut. Kata lho dalam bahasa Indonesia biasa dipakai sebagai kata informatif untuk memastikan / menekankan suatu hal. Pemakaian kata lho ini justru memberikan nuansa budaya dalam bahasa sasaran dan lebih mudah dipahami pembaca yang memiliki latar belakang budaya tersebut daripada menggunakan penerjemahan literal. Jika diterjemahkan secara literal, maka dapat dilihat bahwa kalimat tersebut dituturkan dalam bahasa sumber dengan menggunakan struktur teks yang lengkap secara gramatikal, jika pengalihan pesan mengikuti struktur bahasa pada teks sumber maka akan terkesan aneh karena kalimatnya akan menjadi "Apa saya melakukan kesalahan".

Strategi yang dipilih oleh penerjemah dalam mengalihkan pesan dari bahasa Inggris ke dalam bahasa Indonesia dengan menggunakan strategi penerjemahan kuplet sangat membantu dalam mengatasi permasalahan yang ada karena adanya perbedaan budaya dan struktur bahasa yang berbeda antara bahasa Indonesia dan bahasa Inggris. Penerjemahan pada data 019 menggunakan strategi penerjemahan kuplet dengan menggunakan omission pada penerjemahan auxiliary did, serta padanan budaya yang disesuaikan dengan bahasa pembaca sasaran. Dengan memahami karakter pembaca, maka isi yang tersirat dalam novel akan mampu tersampaikan dengan baik. Sebagaimana kita ketahui bahwa dalam kalimat tanya yang digunakan untuk mengekspresikan sesuatu yang menyatakan terkejut, orang Indonesia biasa menggunakan kata lho.

\section{Ideologi Penerjemahan Ujaran Novel Eclipse Karya Stephenie Meyer dari}

\section{Bahasa Inggris ke dalam Bahasa Indonesia}

Berdasarkan data, dapat dilihat bahwa 30 data tersebut menggunakan ideologi domestikasi. Artinya bahwa budaya sangat berpengaruh besar terhadap pembentukan ideologi penerjemah sehingga penerjemah lebih memilih untuk menggunakan ideologi 
penerjemahan domestikasi. Namun, ada 4 data yang menggunakan ideologi foreignisasi atau pemancanegaraan yaitu pada data 001,021,025, dan 030 .

\begin{tabular}{|l|l|l|}
\hline Ideologi Penerjemahan & No Urut Data & Jumlah \\
\hline Domestikasi & $\begin{array}{l}002,003,004,005,006,007,008,009,010, \\
011,012,013,014,015,016,017,018,019, \\
020,022,023,024,026,027,028,029\end{array}$ & 26 \\
\hline Foreignisasi & $001,021,025,030$ & 4 \\
\hline
\end{tabular}

Berikut ini tampilan data terkait dengan ideologi penerjemahan:

Ideologi Penerjemahan

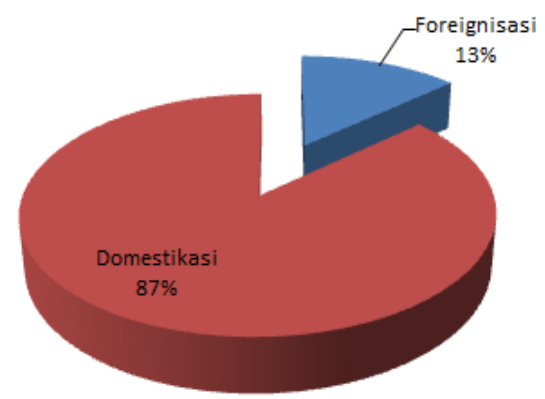

\section{Grafik Sebaran Ideologi Penerjemahan Ujaran Novel Eclipse}

\section{a. Ideologi Penerjemahan Domestikasi}

Berdasarkan data 019, dari perspektif semiotik, dapat dilihat bahwa aspek penanda dari ujaran tersebut yaitu teks sumber itu sendiri, yaitu "What did I do wrong?" dalam bahasa Inggris. Padanan yang bisa kita gunakan untuk mengalihkan kode-kode pada bahasa Inggris sehingga menjadi bahasa Indonesia yang berterima adalah dengan mencari makna yang bisa dibangkitkan dari petanda. Dengan berasumsi bahwa bahasa sasaran adalah bahasa Indonesia sehingga terdapat kebudayaan atau kebiasaan orang Indonesia pada tuturan tersebut dan konteks yang sedang dibicarakan terjadi antara seorang ayah dan anak. Konteks pada tuturan tersebut terjadi pada situasi tidak resmi dan terjadi di dapur serta menunjukkan bahwa suatu kondisi pada saat seorang ayah merasa bahwa dirinya tidak salah dalam memasak spagethi. Dalam berujar dengan lawan bicara yang secara usia lebih muda, orang Indonesia memiliki budaya yang berbeda dengan orang Inggris. Orang Indonesia biasa mengatakan dengan bahasa yang santai dan susunan kata yang tidak formal. Pemakaian kata tho pada penanda bahasa sasaran memiliki hubungan erat dengan budaya orang Indonesia yang menggunakan 
kata tersebut untuk memastikan atau menekankan suatu hal. Jadi dari perspektif semiotik, penerjemahan tersebut sudah tepat dan sesuai dengan maksud bahasa sumber yang ditulis ulang dengan menggunakan bahasa yang berbeda dalam bahasa sasaran. Penerjemah menggunakan ideologi domestikasi yang lebih berorientasi pada bahasa sasaran karena melihat konteks yang ada pada pembicaraan tersebut, yaitu pada situasi yang tidak resmi dan ia berbicara dengan anaknya yang tentunya tidak perlu menggunakan bahasa formal. Pemakaian kata lho menunjukkan bahwa penerjemah berupaya untuk menyampaikan pesan kepada pembaca dengan enak dan mudah dipahami karena sesuai dengan kebiasaan orang Indonesia.

\section{b. Ideologi Penerjemahan Foreignisasi}

Ideologi ini dipakai penerjemah untuk mempertahankan makna pada bahasa sumber, dari 30 data yang dijadikan sampel penelitian, terdapat 4 data yang menggunakan ideologi foreignisasi, yaitu pada data 001,021,025, dan 030 .

Berikut ini contoh data tentang pemakaian ideologi foreignisasi:

\begin{tabular}{|c|l|l|}
\hline $\begin{array}{c}\text { No } \\
\text { Data }\end{array}$ & \multicolumn{1}{|c|}{ Tsu } & \multicolumn{1}{c|}{ Tsa } \\
\hline 030 & “What is it, Mom?” & "Ada apa, Mom?” \\
& & \\
& (Eclipse: 67$)$ & (Gerhana: 82) \\
\hline
\end{tabular}

Dari pandangan semiotik, dapat dilihat bahwa aspek penanda dari ujaran tersebut yaitu teks sumber itu sendiri, yaitu “What is it, Mom?" dalam bahasa Inggris. Padanan yang bisa kita gunakan untuk mengalihkan kode-kode pada bahasa Inggris sehingga menjadi bahasa Indonesia yang berterima adalah dengan mencari makna yang bisa dibangkitkan dari petanda. Jika penerjemah menggunakan penerjemahan harfiah, maka makna yang dihasilkan pada teks sasaran yaitu apa ini ibu? dan penerjemahan ini terasa aneh karena tidak sesuai dengan konteks ujaran antara seorang ibu dan anak yang sedang bercakap-cakap dalam keadaan santai. Namun, dalam penerjemahan pronomina Mom yang dalam bahasa Indonesia memiliki padanan yaitu ibu, mama, atau emak tidak digunakan oleh penerjemah. Penerjemah mengalihkan pesan dengan berorientasi pada bahasa sumber. 


\section{Penilaian Pembaca atas Penerjemahan Ujaran Novel Eclipse Karya} Stephenie Meyer dari Bahasa Inggris ke dalam Bahasa Indonesia

Berikut ini sajian data yang menunjukkan penilaian pembaca atas penerjemahan ujaran novel Eclipse dari bahasa Inggris ke dalam bahasa Indonesia. Responden yang dipilih berasal dari kalangan pembaca novel yang memiliki kemampuan bahasa Inggris tingkat menengah.

\section{a. Penilaian Pembaca terhadap Tingkat Kesepadanan}

Berikut ini sajian data terkait dengan tingkat kesepadanan menurut pembaca.

\section{Kesepadanan}

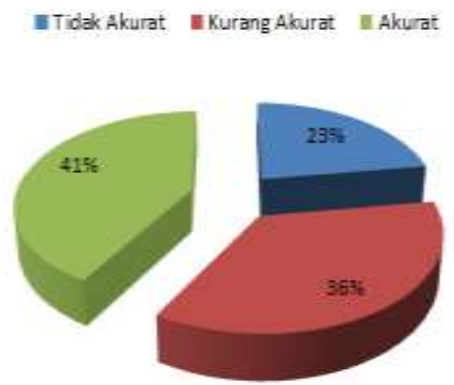

\section{Grafik Tingkat Kesepadanan Penerjemahan}

Berdasarkan persepsi dari pembaca sebagaimana sajian di atas, dapat dilihat bahwa pada penerjemahan ujaran novel Eclipse karya Stephenie Meyer dari bahasa Inggris ke dalam bahasa Indonesia memiliki tingkat kesepadanan yang tinggi, yaitu $41 \% \%$. Artinya bahwa penerjemah mampu mengalihkan pesan pada ujaran dalam TSu secara akurat ke dalam Tsa.

\section{b. Penilaian Pembaca terhadap Tingkat Keberterimaan}

Berikut ini sajian data terkait dengan tingkat keberterimaan menurut respon pembaca.

\section{Keberterimaan}

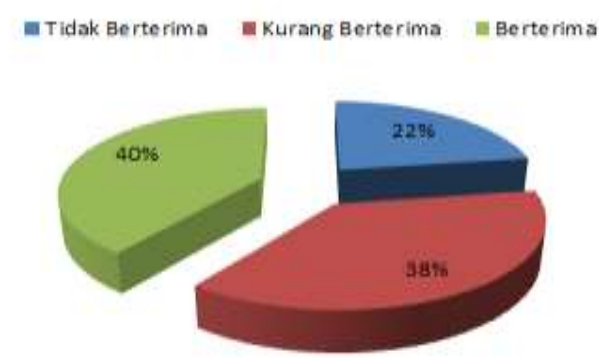

Grafik Tingkat Keberterimaan Penerjemahan 
Berdasarkan persepsi dari pembaca dapat dilihat bahwa pada penerjemahan ujaran novel Eclipse karya Stephenie Meyer dari bahasa Inggris ke dalam bahasa Indonesia memiliki tingkat keberterimaan yang tinggi, yaitu 40\%. Artinya bahwa penerjemahan ujaran tersebut berterima dalam bahasa sasaran.

\section{c. Penilaian Pembaca terhadap Tingkat Keterbacaan}

Berikut ini sajian data terkait dengan tingkat terbacaan menurut pembaca.

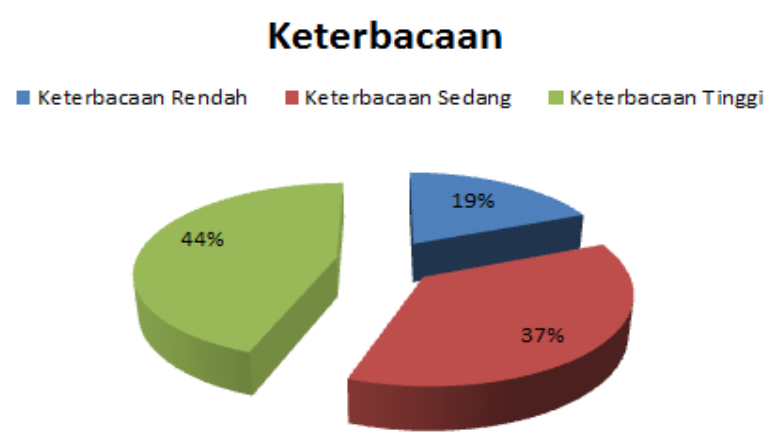

\section{Grafik Tingkat Keterbacaan Penerjemahan}

Berdasarkan persepsi dari pembaca, dapat dilihat bahwa pada penerjemahan ujaran novel Eclipse karya Stephenie Meyer dari bahasa Inggris ke dalam bahasa Indonesia memiliki tingkat keterbacaan yang tinggi, yaitu 44\%. Hal ini berarti bahwa pembaca bisa memahami apa yang dimaksudkan dalam teks sumber sama halnya ketika membaca teks sasaran.

\section{E. Simpulan}

Penerjemahan merupakan proses pengalihan pesan dari teks sumber ke dalam teks sasaran sehingga penerjemah perlu memahami BSu dan BSa sama baiknya. Pada penerjemahan karya sastra, perlu pemahaman terhadap karya sastra itu sendiri karena mengalihkan pesan dalam karya sastra dilakukan melalui proses rekonstruksi ulang yang membutuhkan pemahaman akan keindahan bahasa dalam penyampaiannya. Dalam pengalihan pesan, peran budaya sangat berpengaruh terhadap keberhasilan penerjemah untuk bisa menghasilkan kualitas terjemahan yang baik, hal ini dapat ditelusuri dengan perspektif semiotik untuk melihat hubungan tanda, penanda, dan petanda dalam penerjemahan.

Dalam mengalihkan pesan, penerjemah berupaya mengalihkan pesan sedekat mungkin dengan pembaca sasaran yaitu pada kalangan muda dan menggunakan strategi penerjemahan yang tepat sehingga hasil terjemahan dapat dipahami oleh pembaca. 
Demikian pula dalam ideologi, penerjemah lebih banyak menggunakan ideologi domestikasi yang berorientasi pada bahasa sasaran.

Pada penerjemahan ujaran novel Eclipse karya Stephenie Meyer dari bahasa Inggris ke dalam bahasa Indonesia memiliki tingkat kesepadanan, keberterimaan, dan keterbacaan yang akurat sehingga bisa disimpulkan bahwa penerjemah berhasil dalam mengalihkan pesan teks sumber ke dalam teks sasaran.

\section{F. Daftar Pustaka}

Bell, Roger T.. 1991.Translation and Translating: Theory and Practice. New York: Routledge.

Hoed, Benny Hoedoro. 2006. Penerjemahan dan Kebudayaan. Jakarta: PT Dunia Pustaka Jaya.

2003. Penelitian di Bidang Penerjemahan. Makalah untuk Lokakarya Penelitian STBA LIA, Wisma Karya Sartika, Cipanas.

Newmark, Peter. 1988. A Textbook of Translation. London: Prentice Hall International. 1991. About Translation. Clevedon: Multilingual Matters.

Nord. 1997. Translating as a Purposeful Activity: Functionalist Approaches Explained. Manchester, UK: St. Jerome Publishing. 